INTERNATIONAL JOURNAL OF SYSTEMATIC BACTERIOLOGY

Vol. 18, No. 1 January 1968

pp. $15-17$

Copyright 1968, Iowa State University Press

\title{
REPORT OF THE GENERAL ACTIVITIES OF THE IAMS \\ ADVISORY COMMITTEE ON THE ALLOCATION OF FUNDS TO CULTURE COLLECTIONS FOR THE YEARS 1965, 1966 AND 1967
}

For each year covered in this report the International Union of Biological Sciences appropriated $\$ 2000.00$ for use in maintaining specialized collections of microorganisms that are not kept in public collections (those subsidized or financed by a researchorganization, government department or commercial institution). The fund is administered by the Section on Culture Collections of the International Association of Microbiological Societies through its Advisory Committee on the Allocation of Funds to Culture Collections.

The membership of the Advisory Committee was appointed in 1965 by the President of the Section, Professor V. B. D. Skerman, Brisbane, Australia. Members are:

Haynes, W. C. (Chairman-Secretary), Northern Utilization Research and Development Division, $1815 \mathrm{~N}$. University St. , Peoria, Illinois 61604, U.S.A.

DeLey, J., Laboratory of Microbiology, Casinople in 21, Gent, Belgium.

Shewan; J.M., Ministry of Technology, Torry Research Station, 135 Abbey Road, Aberdeen, Scotland, U. K.

Zhdanov, V.M., Ivanovsky Institute of Virology, U.S.S.R. Academy of Medical Sciences, lst Shchukinsky proyezd 24, Moscow, D-98, U.S.S.R.

Late in 1966, another member was added:

Jagannathan, V., Biochemistry Division, National Chemical

Laboratory, Poona-8, India

The Advisory Committee has adhered to the rules and conditions under which culture collections qualify for funds as set forth by its predecessor. According to the conditions a collection to be eligible for consideration must:

1. Actually maintain cultures of microorganisms, not serve only as an information center.

2. Send cultures as free gifts or in exchange for other cultures, not charge a fee.

3. Send cultures to specialist workers in any part of the world. 
4. Not be supported in whole or in part by funds from a government department, industry, or an international agency such as the Food and Agriculture Organization.

5. Agree to deposit cultures in at least one other permanent collection to insure against loss.

The rules require that

1. Preference will be given to specialized collections of microorganisms that a re not usually maintained in public collections (vide supra).

2. Funds may be granted to cover expenditures for scientific equipment, culture media, glass and plastic ware, experimental animals, salaries for technical help and costs of typing, duplicating, etc.

3. Application must be made to the Chairman-Secretary of the Advisory Committee on prescribed application forms in quintuplicate, in English with monetary amounts expressed in United States dollars, by January $l$ of the year for which funds are requested.

4. Recipients of grants must render an accounting of expenditures at the end of the year to Dr. Karl Egle, Treasurer of IUBS, Botanisches Institut der Johann Wolfgana Goethe Universität, Siesmayerstrasse 70 , Frankfur am Main, Germany.

In 1965, the first year of operation of the current Advisory Committee, applications were received from curators of five culture collections and payments to four of themwere recommended. In this year also, the deadline for receipt of applications was advanced to January 1 of the year for which funds are requested. This change was needed to allow more time for transit of applications and communications and for their consideration.

At the end of 1965 the Advisory Committee was notified that culture collections of medical orientation could no longer receive support with funds derived from I. U.B.S. Two of the collections that received funds in 1965 were medically oriented. Inasmuch as no other organization provides to the Section funds that a re available to medically oriented culture collections, such collections have received no financial aid from the Section since 1965.

In 1966 the Advisory Committee received applications from seven culture collections and recommended payment to five of them. Two of the five had also been granted funds in 1965. 
All who were members of the Advisory Committee in 1965 attended the Ninth International Congress for Microbiology in Moscow in 1966. A meeting, attended by the President of the Section, was held in Building G of Moscow University. Plans were made for more effectively advertising the availability of funds, alternatives to the present more or less unrestricted use by culture collections of grants from I. U.B.S. were discussed, and the application forms were revised and updated.

Four applications for funds were received in 1967, and grants were recommended for three of them. All three had received support also in 1966.

In the three years the current Advisory Committee has been functioning, grants have been made to culture collections in Denmark, England, Germany, India and Israel.

December 31,1967

Respectfully submitted

William C. Haynes

Chairman-Secretary 